\title{
Compressive Strength of Interlocking Concrete Pavement Block influenced by Admixtures
}

\author{
Parinita Baruah, Sudip Basack, Ghritartha Goswami
}

\begin{abstract}
The interlocking concrete pavement blocks are quite commonly used to construct the pedestrian walkways and parking lots of transport infrastructure. Such blocks need adequate compressive strength to withstand the design live loads. In this paper, the influence of admixtures on the compressive strength of the blocks are studied through a series of laboratory investigations. The M35 grade of concrete conforming to the Indian Standard code of practice has been used with a standard superplasticizer as admixtures added at specified weights. The study implied that the use of admixtures alters the compressive strength of concrete blocks significantly.
\end{abstract}

Keywords - Admixtures, concrete block, compressive strength, workability

\section{INTRODUCTION}

$\mathbf{T}_{\mathrm{a}}$ HE versatile use of concrete as a construction material is accepted worldwide for expanding and reshaping the infrastructure development. In case of transport infrastructure in particular, the interlocking concrete pavement blocks are used in bulk for pedestrian walkways and parking areas. These blocks require adequate compressive strength to withstand the imposed live loads. Application of appropriate admixtures in concrete are likely to alter the compressive strength of the concrete blocks.

Karasawa et al. [1] investigated the applicability of fly ash as a substitute for fine aggregate in concrete paving blocks by testing the properties including the strength characteristics. The results showed that for $25 \%$ of fly ash by weight, the optimum values of plastic deformation of $1 \mathrm{~mm}$ and flexural strength of $6 \mathrm{MPa}$ were achieved. This observation indicated the usability of fly ash as a substitute for fine aggregate in the production of concrete blocks for pavement.

Lee et al. [2] conducted laboratory studies on the properties of concrete interlocking blocks dyed with pigments and observed that iron oxide pigments provided higher strength to the concrete blocks.

This work was supported by Gauhati University, Assam, India as a part of the academic research curriculum of the first author herein.

Parinita Baruah is with the Scholar's Institute of Technology \& Management, Guwahati, Assam, INDIA

Sudip Basack is Principal, Elitte College of Engineering, Sodepur, Kolkata, INDIA

Ghritartha Goswami is with the Scholar's Institute of Technology \& Management, Guwahati, Assam, INDIA
Investigations on concrete pavement blocks by Central Road Research Institute, Government of India was summarized by Muraleedharan and Sood [3]. Studies on the infiltration rate, structural properties and performance together with lifespan and physical filtration efficiency of the crumb rubber concrete block pavement was done by Simon et al. [4]. The influence of fly ash content was specifically investigated by Ling et al. [5]. The replacement of crushed sandstone aggregate with concrete and marble wastes in prefabricated concrete interlocking blocks was carried out by Uygunoglu et al. [6]. The infiltration behaviour of interlocking concrete blocks used in car parking was studied by Luis et al. [7] using Cantabrian fixed infiltrometer. Uygunoglu [8] studied the influence of curing condition due to the replacement of cement with fly ash in the concrete blocks.

Sojobi [9] investigated the performance of sawdust wastes as alternative lightweight fine aggregate and laterite as a cementitious material to manufacture a lightweight interlocking concrete paving unit. Parthini and Gifta [10] proposed to produce interlocking concrete pavement blocks using sand without curing in order to reduce the landfill problem. Rajkumar et al. [11] studied the use of bagasse ash in manufacturing the pavement block for low volume traffic road from the viewpoint of economy and convenience.

A typical details of an interlocking pavement structure for pedestrian movement is shown in Fig.1.

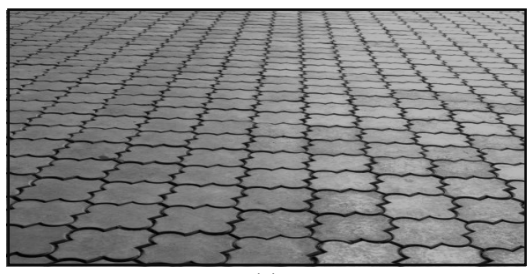

(a)

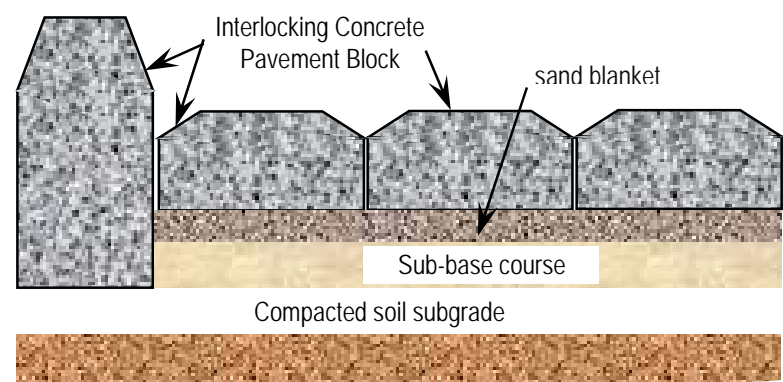

(b)

Fig.1. A typical interlocked pavement: (a) photographic view, and (b) cross sectional details 


\section{Test MATERIALS}

\section{A. Concrete Mix Design}

To manufacture the interlocking concrete pavement blocks in the laboratory, the M35 grade of concrete has been used (characteristic strength being $35 \mathrm{~N} / \mathrm{mm}^{2}$ ). The characteristic strength is defined as the compressive strength, below which not more than $5 \%$ of the test results is expected to fall [12].

Firstly, the relative proportions of different ingredients of the concrete mix has been determined in the laboratory using the appropriate code of practice [13]. The zero-slump concrete is used to produce the pavement blocks, their quality are expected to depend upon the following parameters [14]: capacity of compactor and vibrator, grade of cement, water content, quality of aggregates, their gradation and mix design, additive used, handling equipment employed, curing method, level of supervision, workmanship and quality control.

\section{B. Block Geometry}

The geometry of the manufactured blocks has been summarized as follows [14]:

Mean length $=232 \mathrm{~mm}$

Mean breadth $=175 \mathrm{~mm}$

Mean thickness $=600 \mathrm{~mm}$

The aspect ratio of the specimen (i.e., the ratio of mean length to mean depth) is 3.87, which is less than 4 [14].

The diagrams of the final shape of the manufactured blocks are shown in Fig.2.

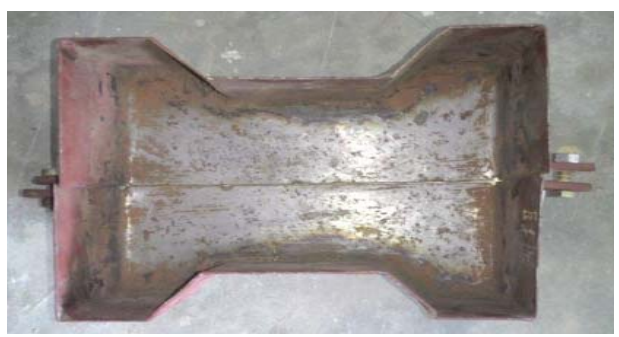

(a)

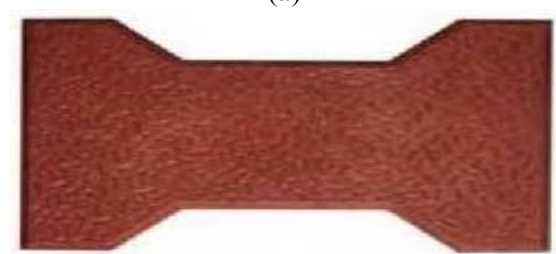

(b)

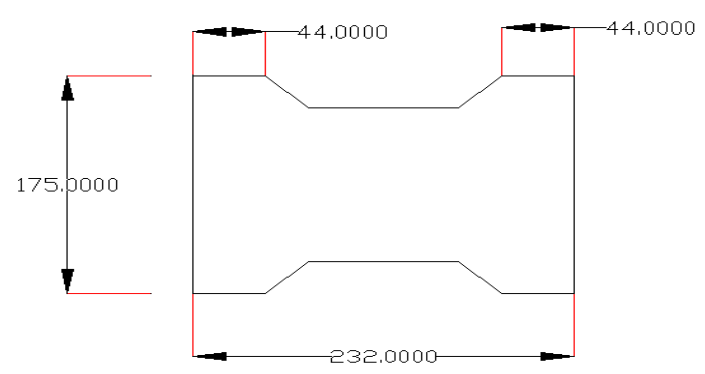

(c)

Fig.2. The manufactured block: (a) photograph of mould, (b) photograph of finished block, and (c) dimensions

\section{TEST SPECIFICATIONS}

The test specifications adopted have been standardized based on the appropriate codes of practice, as summarized in Table I below.

Table I: Details of test specifications

\begin{tabular}{|c|c|c|c|c|}
\hline Ingredient & \multicolumn{2}{|l|}{ Parameter } & Value & Code \\
\hline \multirow{5}{*}{ Cement } & \multicolumn{2}{|c|}{ Normal consistency } & $32.5 \%$ & [15] \\
\hline & \multicolumn{2}{|c|}{ Average fineness } & $95 \%$ & [16] \\
\hline & \multicolumn{2}{|l|}{ gravity } & 3.00 & [17] \\
\hline & \multirow[t]{2}{*}{ Setting time } & Initial & 2 hours & \multirow[t]{2}{*}[15]{} \\
\hline & & Final & 7 hours & \\
\hline \multirow{2}{*}{$\begin{array}{l}\text { Coarse } \\
\text { aggregate }\end{array}$} & \multicolumn{2}{|c|}{$\begin{array}{l}\text { Average specific } \\
\text { gravity }\end{array}$} & 2.54 & {$[17]$} \\
\hline & \multicolumn{2}{|c|}{$\begin{array}{l}\text { Water absorption } \\
\text { (percentage of dry } \\
\text { weight) }\end{array}$} & $0.987 \%$ & $\begin{array}{l}\text { Not } \\
\text { applicable }\end{array}$ \\
\hline \multirow{4}{*}{$\begin{array}{l}\text { Fine } \\
\text { aggregate }\end{array}$} & $\begin{array}{l}\text { Average } \\
\text { gravity }\end{array}$ & pecific & 2.96 & {$[17]$} \\
\hline & \multicolumn{2}{|c|}{ Zonal location } & Zone III & {$[18]$} \\
\hline & \multicolumn{2}{|l|}{ Void ratio } & 0.5 & $\begin{array}{l}\text { Not } \\
\text { applicable }\end{array}$ \\
\hline & \multicolumn{2}{|l|}{ Porosity } & 0.13 & $\begin{array}{l}\text { Not } \\
\text { applicable }\end{array}$ \\
\hline
\end{tabular}

Using the above test specifications, the mix design obtained [13] are summarized in Table II below.

Table II: Concrete mix designs

\begin{tabular}{|c|c|c|c|}
\hline Category & $\begin{array}{c}\text { Cement } \\
\text { grade }\end{array}$ & $\begin{array}{c}\text { Super-plasticizer } \\
\text { quantity by } \\
\text { weight (\%) }\end{array}$ & $\begin{array}{c}\text { Mix design } \\
\text { (Cement: FA: CA) }\end{array}$ \\
\hline A & PPC & 1.0 & $1: 2.28: 2.35$ \\
\hline B & PPC & 1.5 & $1: 1.79: 2.77$ \\
\hline C & PPC & 2.0 & $1: 2.26: 2.33$ \\
\hline D & PPC & 0.0 & $1: 1.98: 2.04$ \\
\hline E & OPC & 2.0 & $1: 2.268: 2.34$ \\
\hline \multicolumn{3}{|c|}{ - PCC: Pozzolanic Portland Cement } \\
• OPC: Ordinary Portland Cement \\
- FA: Fine aggregate; CA: Coarse aggregate \\
\hline
\end{tabular}

The super-plasticizer applied herein with the concrete mix had been sulfonated naphthalene formaldehyde which is categorized as a synthetic polymer (specific gravity at $25^{\circ} \mathrm{C}=$ 1.06; $\mathrm{pH}>6$ ). Such additive increases the strength of concrete while retard the curing time [19].

\section{RESULTS AND DISCUSSIONS}

The interlocking concrete pavement blocks manufactured using the mix designs were casted and cured for 28 days. Thereafter, the compressive strength of the specimen was tested using universal compressive testing machine [20, 21]. 
The results obtained is presented in Table III below.

Table III: Test results

\begin{tabular}{|c|c|c|c|c|}
\hline $\begin{array}{c}\text { Cement } \\
\text { grade }\end{array}$ & $\begin{array}{c}\text { Super- } \\
\text { plasticizer } \\
\text { quantity } \\
\text { by weight } \\
\text { (\%) }\end{array}$ & $\begin{array}{c}\text { Weight } \\
\text { of the } \\
\text { block } \\
\mathbf{( k g )}\end{array}$ & $\begin{array}{c}\text { Compressive } \\
\text { strength of } \\
\text { the block } \\
\text { (N/mm } \mathbf{2})\end{array}$ & $\begin{array}{c}\text { Increase in } \\
\text { compressive } \\
\text { strength of } \\
\text { the block } \\
\text { (\%) }\end{array}$ \\
\hline PPC & 0.0 & 4.877 & 14.79 & Not applicable \\
\hline PPC & 1.0 & 4.124 & 20.44 & 38.2 \\
\hline PPC & 1.5 & 4.805 & 35.68 & 141.24 \\
\hline PPC & 2.0 & 3.986 & 6.09 & -58.82 \\
\hline OPC & 2.0 & 3.982 & 11.6 & -21.57 \\
\hline
\end{tabular}

The variation of weights of the blocks for different grades of concrete and different quantities of super-plasticizers are portrayed in the bar chart shown in Fig.3 below. As observed, the weight attains the maximum value for category A, i.e., PCC with no super-plasticizer. Adding 2\% super-plasticizer, the weight assumes its lowest value for both PPC and OPC, while the values are higher in case of lower quantities of super-plasticizer, i.e., $1 \%$ and $1.5 \%$.

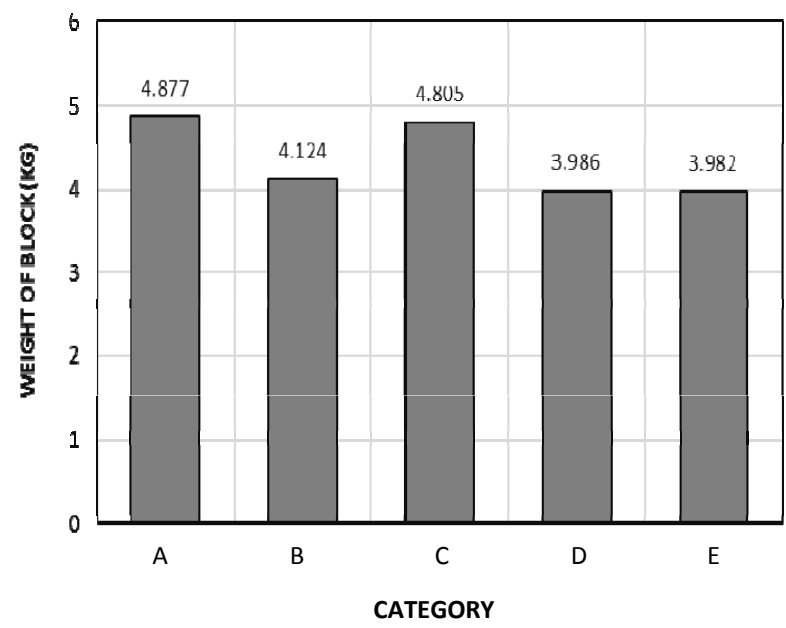

Fig.3. Bar chart for weights of different categories of blocks

The variation of compressive strength of the blocks with the quantity of additive has been plotted in Fig.4. It is observed that the compressive strength of the blocks varies in a nonlinear pattern with the quantity of additive. Initially the compressive strength increases until a peak value is attained and decreases thereafter. The maximum compressive strength has been found to be $36 \mathrm{MPa}$ for the value of additive quantity as $1.48 \%$.

The variation of increase in compressive strength of the blocks with the quantity of additive has been plotted in Fig.5. As observed, the pattern of variation is parabolic with descending slope. The peak value of increase was found as $150 \%$ for the value of additive quantity as $1.45 \%$.

The super-plasticizer acts as dispersants which minimizes particle segregation of concrete mass due to interaction of the oppositely charged particles of polymers and colloids. This is the possible reason for the above observations of the test results [22]. See some relevant results in [23] as well.

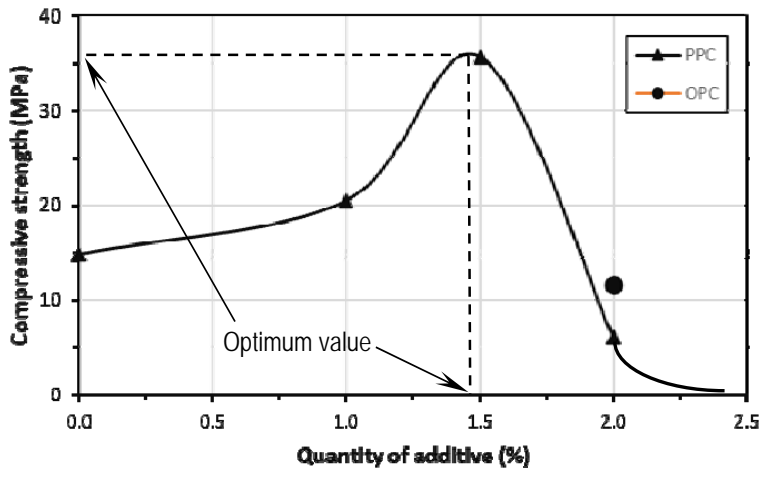

Fig.4. Variation of compressive strength with quantity of additive

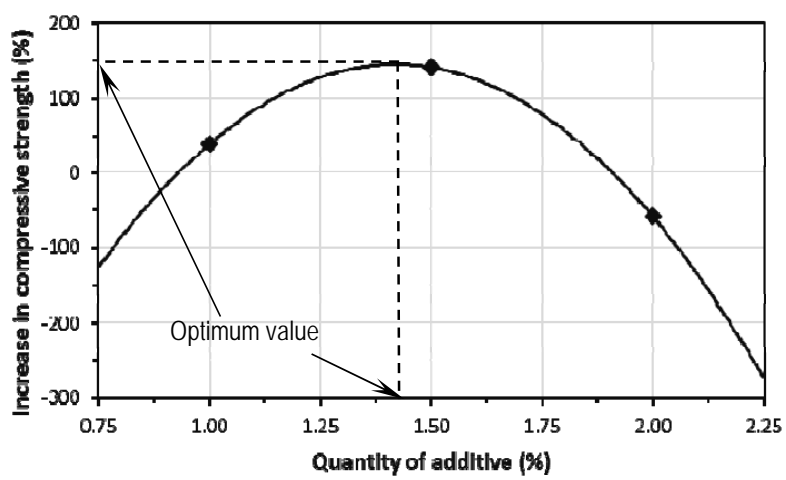

Fig.5. Variation of increase in compressive strength with quantity of additive

\section{CONCLUSION}

The interlocking concrete pavement blocks used in pedestrian walkways and car parks required adequate compressive strength to withstand the imposed live loads. Addition of appropriate additives increases the strength to an optimum level.

The study implies that that a peak value of compressive strength is attained when the super-plasticizer is applied as additive at a quantity of $1.45-1.48 \%$ by weight of the concrete mass. The pattern of variation of compressive strength and its relative increase with the additive quantity are both nonlinear.

\section{ACKNOWLEDGMENT}

The authors thankfully acknowledge the financial and infrastructure assistances received from Gauhati University to carry out the investigation. Finalization of the manuscript was done at Elitte College of Engineering, Sodepur, Kolkata, India. 


\section{REFERENCES}

[1] A. Karasawa, S. Suda, H. Naito and H. Fujiwara, "Application of fly ash to concrete paving block," in Proc. $7^{\text {th }}$ International Conference on Concrete Block Paving, ISBN: 0-958-46091-4, 12-15 Oct. 2003, Sun City, South Africa.

[2] H. S. Lee., J. Y. Lee. and M. Y. Yu., "Influence of iron oxide pigments on the properties of concrete interlocking blocks," Cement and Concrete Research, vol. 33, pp. 1889-1896, 2003.

[3] T. Muraleedharan and V. K. Sood, "Past and present efforts for popularisation of interlocking concrete block pavement technology in India," in Proc. $7^{\text {th }}$ International Conference on Concrete Block Paving, ISBN: 0-958-46091-4, 12-15 October 2003, Sun City, South Africa.

[4] S. Beecham, D. Pezzaniti, B. Myers, B. Shackel and A. Pearson, "Experience in the application of permeable interlocking concrete paving in Australia," in Proc. $9^{\text {th }}$ International Conference on Concrete Block Paving, October 2009, Buenos Aires, Argentina, 18-21.

[5] T. C. Ling., H. M. Nor, M. R. Hainin and A. A. Chik, "Laboratory performance of crumb rubber concrete block pavement," International Journal of Pavement Engineering, vol. 10, no. 5, 2009, pp. 361-374

[6] T. Uygunoglu, I. B. Topcu, O. Gencel and W. Brostow, "The effect of fly ash content and types of aggregates on the properties of pre-fabricated concrete interlocking blocks (PCIBs)," Construction and Building Materials, vol. 30, 2012, pp. 180-187.

[7] A. Luis, S. Fontaneda, J. R. Hernandez, A. V. Zamanillo and D. C. Fresno, "Laboratory analysis of the infiltration capacity of interlocking concrete block pavements in car parks," Water Science and Technology, vol. 67, no.3, 2013, pp. 675-681.

[8] T. Uygunoğlu, "Comparison of properties of prefabricated interlocking pavement blocks cured at different conditions," Revista de la Construcción, vol. 15, no. 2, 2016, pp. 125-134.

[9] A. O. Sojobi, "Evaluation of the performance of eco-friendly lightweight interlocking concrete paving units incorporating sawdust wastes and laterite," Cogent Engineering, vol. 3, 2016, pp. 1-27.

[10] S. Parthini and C. Gifta, "Experimental investigation on cost effective paver block," International Journal of Advanced Research Trends in Engineering and Technology, vol. 3, Special Issue 2, 2016, pp. 823-827.

[11] P. R. K. Rajkumar, D. K. Krishnan, P. T. Ravichandran and A. T. Harini, "Study on the use of bagasse ash paver blocks in low volume traffic road pavement," Indian Journal of Science and Technology, vol 9, no. 5, 2016, pp. 1-6.

[12] Bureau of Indian Standard, "Plain and reinforced concrete - code of practice," IS-456: 2000, April 2007.

[13] Bureau of Indian Standard, "Concrete mix proportioning - guidelines,' IS-10262: 2009.

[14] Bureau of Indian Standard, "Precast concrete blocks for paving specification," IS-15658: 2006

[15] Bureau of Indian Standard, "Methods of physical tests for hydraulic cement - part 14: determination of false set," IS-5513: 1996.

[16] Bureau of Indian Standard, "Sieves, sieving and other sizing methods," IS-460: 1965.

[17] Bureau of Indian Standard, "Methods of test for aggregates for concrete," IS-2386 (Part III): 1965.

[18] Bureau of Indian Standard, "Specification for coarse and fine aggregates from natural sources for concrete," IS-383: 1970, September 1993.

[19] G. Bye, P. Livesey and L. Struble, "Admixtures and Special Cements," Portland Cement: Third edition, 2011, doi:10.1680/pc.36116.185. ISBN 978-0-7277-3611-6.

[20] C. Wu, Q. Chen, S. Basack and R. Xu, "Biaxial creep test study on the influence of structural anisotropy on rheological behaviour of hard rock," Journal of Materials in Civil Engineering, vol. 28, issue 10, 2016, pp. 04016104-1-12.

[21] C. Wu, Q. Chen, S. Basack and S. Karekal, "Laboratory investigation on rheological properties of greenschist considering anisotropy under multistage compressive creep condition," Journal of Structural Geology, vol. 114, 2018, pp. 111-120.

[22] V. S. Ramachandran, "Concrete Admixtures Handbook - Properties, Science, and Technology," $2^{\text {nd }}$ Edition, 1995, William Andrew Publishing, ISBN 0-8155-1373-9 p. 121

[23] Ekaterina Rouvinskaya, Oxana Kurkina, Andrey Kurkin, Andrey Zaytsev, Modeling of Internal Wave Impact on Hypothetical Pillars of Hydraulic Engineering Constructions in the Conditions of the Sakhalin
Island Shelf, WSEAS Transactions on Fluid Mechanics, Volume 13, 2018, pp. 101-107

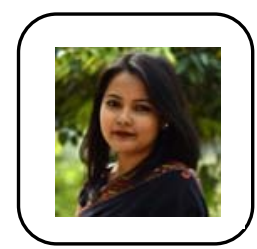

Parinita Baruah, BE, M.Tech., is currently the Assistant Professor at Scholar's Institute of Technology and Management, Guwahati, Assam, India. She graduated in civil engineering in the year of 2016 from Gauhati University, India and postgraduated in construction engineering in the year of 2018 from Assam Don Bosco University, India.

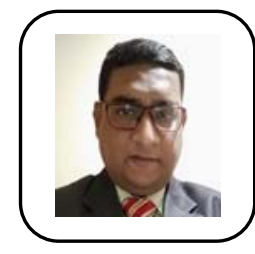

Sudip Basack, PhD, FIE, M.ASCE is a civil engineering professional with vast academic experience at responsible senior positions in India and abroad. He published more than 100 technical papers in reputed journals and conferences and is recipient of several research awards at national and international levels. He is an active reviewer of numerous top-class international journals. He has supervised more than 10 research students at postgraduate (Masters and $\mathrm{PhD}$ ) levels and executed sponsored research projects in different Universities. He has undertaken several academic visits in many countries including USA, UK, Germany, Australia, New Zealand, Singapore, China, etc.

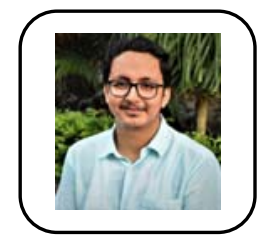

Ghritartha Goswami, BE, M.Tech. is a Professional civil and water resources engineer and currently an Assistant Professor at Scholar's Institute of Technology and Management, Guwahti, Assam, India. He graduated in civil engineering in the year of 2017 from Nagpur University, Maharashtra, India and post-graduated in water resources engineering in the year of 2019 from Assam Kaziranga University, Jorhat, Assam, India. He has participated in various renowned conferences and presented papers. 